\title{
BIOACTIVITY GUIDED CYTOTOXIC ACTIVITY OF CLITORIA TERNATEA UTILIZING BRINE SHRIMP LETHALITY BIOASSAY
}

AKM SHAHIDUR RAHMAN ${ }^{1}$, IQBAL ARSLAN ${ }^{2}$, RAMA SAHA $^{3}$, NIRUPAMA TALUKDER $^{4}$, SMA KHALEQUE $^{5}$, HUSNE ARA ALI $^{6}$

Senior Lecturer ${ }^{1}$, Department of Pharmacology \& Therapeutics, Kumudini Women's Medical College, Mirzapur, Tangail, Professor \& Chairman², Department of Bio-chemistry, BSMMU, Shahbag, Dhaka, Assistant Professor ${ }^{3}$, Department of Pharmacology \& Therapeutics, Faridpur Medical College, Faridpur, Assistant Professor ${ }^{4}$, Department of Forensic Medicine, Moulana Bhasani Medical College, Uttara, Dhaka, Associate Professor ${ }^{5}$, Department of Microbiology, Moulana Bhasani Medical College, Uttara, Dhaka, Ph. D Researcher ${ }^{6}$, Department of Clinical Pharmacy \& Pharmacology, University of Dhaka, Dhaka

\begin{abstract}
The crude methanol extract of leaves, seeds and stem-bark of Clitoria ternatea demonstrated a significant cytotoxic activity in a brine shrimp lethality bioassay test. The LC50 values of the crude methanol extract of leaves, seeds and stem-bark were found to be $25.82,110.92,179.89 \mu \mathrm{gm} / \mathrm{ml}$ respectively. Among them crude methanol extract of leaves $(25.82 \mu \mathrm{gm} / \mathrm{ml})$ and methanol fraction of leaves $(22.28 \mu \mathrm{gm} / \mathrm{ml})$ showed a very promising cytotoxic activity. Further studies have been suggested to discover a novel bioactive compound from methanol fraction of leaves of Clitoria ternatea.
\end{abstract}

(Bangladesh J Physiol Pharmacol 2006; 22(1/2) : 18-21)

\section{INTRODUCTION}

Clitoria ternatea (Family- Liguminoceae, previously known as Papillioneceae), a perennial twining herb, stems terete, more or less pubscent. Leaves imperipinnate, petioles $2-2.5 \mathrm{~cm}$ long; stipules $4 \mathrm{~mm}$ long, linear, acute. Leaflets 5-7, subcoriaceous, 2.5-5 by $2-3.2 \mathrm{~cm}$, elliptic-oblong, obtuse or caute; stipules filiform. Flowers -axillary, solitary, standard bright or blue or sometimes white, with an orange centre, seed$6-10$, yellowish brown, smooth. Two types- white variety and blue flowered variety; widely distributed throughout Bangladesh, used as ornamental plant ${ }^{1}$. Since the plant is reputed for its folkloric uses in various diseases 2 , it draws our attention for its pharmacological screening.

For pharmacological screening, we have applied the brine shrimp lethality bioassay method which is recently developed a rapid general bioassay technique for the natural products, this method indicates cytotoxicity as well as a wide range of pharmacological

Address of correspondence: Dr. AKM Shahidur Rahman, Senior Lecturer, Department of Pharmacology \& Therapeutics, Kumudini Women's Medical College, Mirzapur, Tangail. Mobile- 01912175494 , e-mail: drshaheen20032003@yahoo.com activities e. g. anticancer, antiviral and pesticidal etc 3.4. In this technique, in vitro lethality in a simple zoological organism (brine shrimp nauplii) is used as a convenient monitor for screening and fractionation in the discovery of novel even new bioactive natural products.

Clitoria ternatea is a very bioactive plant and used in various diseases as folklore medicine 5 . Recent study showed that it has anxiolytic, antidepressant, anticonvulsant and antistress activity 6 . Another study showed that root of Clitoria ternatea has anti-inflammatory, analgesic and antipyretic properties ${ }^{7}$. No study on cytotoxic activity has been reported.

Many bioactive compounds have been isolated from different parts of Clitoria ternatea. Recent study showed that malonylated flavonol glycosides were isolated from the petals of Clitoria ternate ${ }^{8}$. Another study demonstrated that new anthocyanins, ternatins $\mathrm{C} 1-\mathrm{C} 5$ and $\mathrm{D} 3$ and preternatins $A 3$ and $C 4$ were isolated from the young Clitoria ternatea flowers ${ }^{9}$. It was also reported that five new anthocyanins, ternatins $A 3, B 3, B 2$ and D2 isolated from Clitoria ternatia ${ }^{10}$.

The deficiencies of the presently available anticancer drugs together with the scientific interest and 
economical consideration, have drawn our attention to the time immemorial plant materials have been used by mankind for treatment of various diseases. In the last two centuries therapeutic agents have been extracted out of plant sources and many drugs have been found there way into Doctor's prescription all over the world ${ }^{11}$.

Traditional indigenous plants those are used to their cytotoxic, antibacterial, antifungal, antiviral and antidiabetic properties. Bangladesh is good repository of natural vegetative and medicinal plants and people have used them for various types of diseases. The use of drugs obtained from the medicinal plants has increase not only in developed world but also in our country in recent time.

Scientific development in the research field of indigenous medicinal plants in a significant aspect to have safer anti-cancer principles through their identification, isolation, characterization and biological testing. In the field of cancer chemotherapy there are many drugs are available in the world ${ }^{12}$. But due to their potential side effects, clinical toxicities, adverse effect ${ }^{13-14}$ and rapid development of resisrance ${ }^{15,16,17}$, then need to discover of a new novel, safe, most effective drugs.

\section{MATERIALSAND METHODS}

Collection of plant materials: The leaves, seeds and stem-bark of Clitoria ternatea, an ornamental plant, were collected from a family garden of a house of Sirajgonj and the plant was taxonomically identified by Department of Botany, University of Dhaka.

Extraction, fractionation and primary pharmacological screening: About $3 \times 500$ gm air dried and powered leaves, seeds and stem-bark, each of which were extracted with 1 litre of methanol and filtered off. The 3 filtrates (10 gm each) were evaporated to dryness in vacuo ${ }^{17}$. Because of it was bioactivity-guided investigation; our main aim to identify which crude extract was bioactive, before going to fractionation of the crude extract. In this regard, the cytotoxic activity (described below) of 3 (three) crude extract were done by using brine shrimp lethality bioassay method. From this, we found methanol crude extract of leaves demonstrated a significant cytotoxic activity. So it draws our attention to do the sequential partition fraction of methanol crude extract of leaves in this regard. The sequential partition fraction of methanol crude extract of leaves were then made by using different solvent systems ( $n$-hexane, dichloromethane, methanol) in a simple column chromatography packed with silica gel (column grade) and first extracted with $n$-hexane $(3 \times 100)$, then dichloromethane $(3 \times 100)$ and finally with methanol $(3 \times 100)$. All 3 (three) fractions of leaves were then evaporated to dryness under vacuo to get the $n$-hexane, dichloromethane, methanol fractions respectively. These 3 fractions were then employed in the brine shrimp lethality bioassay.

Pharmacological screening: Brine shrimp lethality bioassay method was applied for pharmacological screening. The eggs of brine shrimp, Artemia salina leaches were collected from pet shop at Katabon market, Dhaka and used as the test organism. The eggs were taken in a conical flask and seawater (prepared by dissolving $38 \mathrm{gm}$ of $\mathrm{NaCl}$ in one litre of distilled water) was added to it. Two days were allowed to hatch the shrimp and to be matured as nauplii.

Measured amount of each sample (the methanol crude extract of seeds, leaves and stem-bark and 3 fractions of leaves) were dissolved in specific volume of DMSO (di-methyl sulfoxide) to obtained the desired concentration of prepared solution as $2000 \mu \mathrm{gm} / 30 \mathrm{ml}$. Then a series of solutions of lower concentrations were prepared from this solution by serial dilution with DMSO. Thus the concentrations of the solutions were obtained as $2000 \mu \mathrm{gm} / 30 \mathrm{ml}, 1000 \mu \mathrm{gm} / 30 \mu \mathrm{l}, 500 \mu \mathrm{gm} / 30 \mu \mathrm{l}$, $250 \mu \mathrm{gm} / 30 \mu \mathrm{l}, \quad 125 \mu \mathrm{gm} / 30 \mu \mathrm{l}, \quad 62.5 \mu \mathrm{gm} / 30 \mu \mathrm{l}$, $31.25 \mu \mathrm{gm} / \mu \mathrm{l}, 15.63 \mu \mathrm{gm} / 30 \mu \mathrm{l}, 7.81 \mu \mathrm{gm} / 30 \mu \mathrm{l}$ and $3.90 \mu \mathrm{gm} / 30 \mu \mathrm{l}$. From each of these solutions $(30 \mu \mathrm{l})$ were added to pre-marked glass vials containing $5 \mathrm{ml}$ of seawater and 20 shrimp nauplii. So the final concentration of samples in the vials was $400 \mu \mathrm{gm} / \mathrm{ml}$, $200 \mu \mathrm{gm} / \mathrm{ml}, 100 \mu \mathrm{gm} / \mathrm{ml}, 50 \mu \mathrm{gm} / \mathrm{ml}, 25 \mu \mathrm{gm} / \mathrm{ml}$, $12.5 \mu \mathrm{gm} / \mathrm{ml}, 6.25 \mu \mathrm{gm} / \mathrm{ml}, 3.125 \mu \mathrm{gm} / \mathrm{ml}$ respectively. For each concentration, one test tube containing the same volume of DMSO plus seawater and brine shrimp nauplii was used as control group. After 24 hours, the test tubes were observed with a magnifying glass and number of survived nauplii in each test tube was counted. From this data, the percent (\%) of the lethality/ mortality of brine shrimp nauplii was calculated for each concentration.

\section{RESULTS}

The results of the brine shrimp lethality bioassay is shown in Table-I \& Table-ll 
Table-I

Brine shrimp lethality bioassay of methanol crude extract of leaves, seeds and stem-bark of Clitoria ternatea-

\begin{tabular}{|c|c|c|c|c|}
\hline Test solution & Concentration $\mu \mathrm{gm} / \mathrm{ml}$ & $\log C$ & $\%$ Mortality & $\mathrm{LC}_{50} \mu \mathrm{gm} / \mathrm{ml}$ \\
\hline Methanol crude & 3.125 & 0.495 & 16.66 & \multirow{8}{*}{25.82} \\
\hline \multirow[t]{7}{*}{ extract of leaves } & 6.25 & 0.7956 & 30 & \\
\hline & 12.5 & 1.095 & 37 & \\
\hline & 25 & 1.398 & 48.33 & \\
\hline & 50 & 1.699 & 66.33 & \\
\hline & 100 & 2 & 81.66 & \\
\hline & 200 & 2.301 & 95 & \\
\hline & 400 & 2.602 & 100 & \\
\hline Methanol crude & 3.125 & 0.495 & 0 & \multirow{8}{*}{110.92} \\
\hline \multirow[t]{7}{*}{ extract of seeds } & 6.25 & 0.7956 & 10 & \\
\hline & 12.5 & 1.095 & 18.33 & \\
\hline & 25 & 1.398 & 23.33 & \\
\hline & 50 & 1.699 & 38.33 & \\
\hline & 100 & 2 & 48.33 & \\
\hline & 200 & 2.301 & 61.66 & \\
\hline & 400 & 2.602 & 76.66 & \\
\hline Methanol crude & 3.125 & 0.495 & 0 & \multirow{8}{*}{179.89} \\
\hline \multirow[t]{7}{*}{ extract of stem-bark } & 6.25 & 0.7956 & 6 & \\
\hline & 12.5 & 1.095 & 12.66 & \\
\hline & 25 & 1.398 & 25 & \\
\hline & 50 & 1.699 & 35 & \\
\hline & 100 & 2 & 41.66 & \\
\hline & 200 & 2.301 & 53.33 & \\
\hline & 400 & 2.602 & 61.66 & \\
\hline
\end{tabular}

Table-II

Brine shrimp lethality bioassay of 03 fractions leaves-

\begin{tabular}{|c|c|c|c|c|}
\hline Test solution & ntration $\mu \mathrm{gm} / \mathrm{ml}$ & $\log C$ & $\%$ Mortality & $\mathrm{LC}_{50} \mu \mathrm{gm} / \mathrm{ml}$ \\
\hline \multirow[t]{8}{*}{ Hexane fraction of leaves } & 3.125 & 0.495 & 5 & \\
\hline & 6.25 & 0.7956 & 11.66 & \\
\hline & 12.5 & 1.095 & 21.66 & \\
\hline & 25 & 1.398 & 30 & \\
\hline & 50 & 1.699 & 40 & 115.24 \\
\hline & 100 & 2 & 48.33 & \\
\hline & 200 & 2.301 & 66.66 & \\
\hline & 400 & 2.602 & 78.33 & \\
\hline \multicolumn{5}{|c|}{ Di-chloromethane fraction of leaves } \\
\hline & 3.125 & 0.495 & 10 & \\
\hline & 6.25 & 0.7956 & 18.33 & \\
\hline & 12.5 & 1.095 & 26.66 & \\
\hline & 25 & 1.398 & 41.66 & 31.55 \\
\hline & 50 & 1.699 & 58.33 & \\
\hline & 100 & 2 & 80 & \\
\hline & 200 & 2.301 & 91.66 & \\
\hline \multirow[t]{9}{*}{ Methanol fraction of leaves } & 400 & 2.602 & 100 & \\
\hline & 3.125 & 0.495 & 10 & \\
\hline & 6.25 & 0.7956 & 18.33 & \\
\hline & 12.5 & 1.095 & 33.33 & \\
\hline & 25 & 1.398 & 51.66 & \\
\hline & 50 & 1.699 & 80 & 22.28 \\
\hline & 100 & 2 & 90 & \\
\hline & 200 & 2.301 & 100 & \\
\hline & 400 & 2.602 & 100 & \\
\hline
\end{tabular}




\section{DISCUSSION}

In this cytotoxic activity study, different mortality rate of the nauplii was observed in all experimental groups where as at same time control group of nauplii remained unchanged (no lethality/mortality). This indicated that the methanol crude extract of leaves and 3 fractions ( $n$ hexane, di-chloromethane, methanol) obtained from it, have demonstrated a promising cytotoxic activity. Each of the test samples showed different mortality rates at the different concentration. The rate of mortality of nauplii was found to be increased in concentration of each of the samples. A plot of log of test samples concentration versus percentage of mortality on the graph paper showed an approximate linear correlation between them ${ }^{18}$. From this graph, the $L C_{50}$ of methanol crude extract of leaves, seeds, stem-bark and 3 fractions of leaves were 25.82, 110.92, 179.89, 115.24, 31.55, 22.28 $\mu \mathrm{gm} / \mathrm{ml}$ respectively. However, Methanol fraction of leaves was found to have more potent with minimum $L_{50}$ $(22.28 \mu \mathrm{gm} / \mathrm{ml})$ then the other extracts/fractions.

\section{ACKNOWLEDGEMENT}

The authors would like to thank Dr. Mohammad Shawkat Ali, Associate Professor, Department of Clinical Pharmacy and Pharmacology, University of Dhaka for give us permission to use his Pharmacological Experiment Laboratory for various phytochemical and cytotoxic activity (Brine shrimp lethality bioassay).

\section{REFERENCES}

1. Kirtikar KR, Basu, BD. Indian Medicinal Plants; Publisher: Bishen Singh, Mahandra Pal Singh; Dehradun, India. 1980; 1: 802 .

2. Kirtikar KR, Basu BD. Indian Medicinal Plants; Volume1; Publisher: Bishen Singh, Mahandra Pal Singh; Dehradun, India. 1980: 803

3. Mayer BN, Ferrigny NR, Putman JE, Jacobsen HB, Nicols $B D$, Mclanghlin JL. Brine Shrimp: convenient bioassay for active plant constituents. Planta Med 1982; 45: 31-4.

4. Mclanghlin JL. Bench-top bioassay for the discovery of bioactive compounds in higher plants. Brenesia 1990:29.
5. Evans WC. Pharmacognosy; W. B. Saunders; 15 th edition; Edinburgh; 2002:475

6. Jain NN. Pharmacol Biochem Behav. 2003; 75(3): 529-36.

7. Devi BP. Anti-inflammatory, analgesic and anti-pyretic properties of Clitoria ternatea root; Fitoterapia. 2003 Jun; 74(4): 345-9.

8. Kazuma K. Malonylated flavonol glycosides from the petals of Clitoria ternatea. Phytochemistry. 2003; 62(2):22937.

9. Terahara, N.; Eight new anthocyanins, ternatins C1-C5 and D3 and preternatins $\mathrm{A} 3$ and $\mathrm{C} 4$ from young Clitoria ternatea flowers. J Nat Prod. 1998; 61(11): 1361-7.

10. Terahara N. Five new anthocyanins, ternatins A3, B4, B3, B2 and D2 from Clitoria ternatea flowers. J Nat Prod. 1998; 61(11): 1361-7.

11. Hardman JG, Limbard LE. Goodman \& Gilman's The Pharmacological Basis of therapeutics, McGraw-Hill, London, 9th edition, 1996:1228-29.

12. Hardman, J. G.; Limbard, L. E.; Goodman \& Gilman's The Pharmacological Basis of therapeutics, McGraw-Hill, London, 9th edition, 1996:1227-29.

13. Hardman JG, Limbard LE. Goodman \& Gilman's The Pharmacological Basis of therapeutics, McGraw-Hill, London, 9th edition, 1996:1238-75.

14. Harrap KR, Davis W, Calvert AH. Cancer chemotherapy and selective drug development, Martinus Nijhoff Publishing, USA; 1984: 5-10.

15. Devita VT. The relationship between tumour resistance to chemotherapy. Cancer 1983; 51: 1209-1220.

16. Hardman JG, Limbard LE. Goodman \& Gilman's The Pharmacological Basis of therapeutics, McGraw-Hill, London, 9th edition, 1996:1237-58.

17. Evans WC. Pharmacognosy; W. B. Saunders; 15th edition; Edinburgh; 2002:137-40.

18. Goldstein A, Aronow L, Kalkan SM. Principles of Drug action. 2nd edition; Wiley Biomedical Health Publication: New York 1974: 376-81. 